\title{
The Role of Deep Brain Stimulation Procedure on the Quality of Life in Patients with Parkinson's Disease
}

1 Diana Dragija

1 Olivera Mihordin

1 Department of Neurosurgery, University Hospital Dubrava, Zagreb, Croatia

Article received: 31.01.2018.

Article accepted: 16.07.2018.

Author for correspodence:

Diana Dragija

Department of Neurosurgery, University Hospital Dubrava

Avenija Gojka Šuška 6, Zagreb, Croatia

Phone: +3851290 2995, +385981321022

E-mail: dragijadiana@gmail.com

DOI: $10.24141 / 2 / 2 / 2 / 3$

Keywords: deep brain stimulation, Parkinson's disease, electrodes, subthalamic nucleus

\section{Abstract}

Introduction. Deep Brain Stimulation (DBS) is an electrical stimulation of the individual cells of the central nervous system. DBS is today most often used to treat movement disorders such as Parkinson's disease, dystonia, Tourette syndrome etc. The goal of DBS is improving the quality of life of patients, specifically by improving their motor function, reduction in drug therapy they use as well as reducing pain and neurological deficits.

Methods. We analyzed the quality of life pre- and post-operatively in 95 patients with DBS implantations. The patients were operated on at the Department of Neurosurgery of the University Hospital Dubrava in Zagreb for treating Parkinson's disease. The patients which were included were operated on from 2007-2015. All patients underwent this highly specialized procedure that consists of implanting electrodes in the subthalamic nuclei (STN) as well as extension and battery implantation.

Results. Four characteristics were analyzed: the patient's ability to clothe, eat and walk independently without assistance as well as their overall satisfaction with the quality of life after the procedure. After the onset of the stimulation, improvement wwas seen in all of the observed parameters.

Conclusion. This kind of procedure has been shown to be justified in treating Parkinson's disease symptoms and improving the quality of life and independence in these patients. 


\section{Introduction}

Stimulation stands for excitation, arousal or activation. There are a couple of ways for brain stimulation. Best known non-invasive techniques are medication induced ones and magnetic stimulation via electrical devices (1). The brain is an electrochemical organ and brain activity controls our physical balance as well as our life. Brain waves are responsible for our way of thinking and how we respond to our surroundings, although there are conditions where this balance is damaged and those conditions require a change in certain brain activities. Deep Brain Stimulation (DBS) is an innovative surgical treatment which provides a precise way of electrical stimulation to certain groups of brain cells and centers (2). First DBS implantation was performed in the 1980s in France. In the USA, DBS has become a routine procedure in 250 medical centers where 125000 patients were treated. In 1993. this procedure was approved in Europe. In the Republic of Croatia, it has been conducted since the year 2000. University hospital Dubrava is unique for its application in this part of Europe.

DBS gives hope to those affected by progressive, neurodegenerative and disempowering diseases which are the reason for their social and psychological isolation. The best results in DBS are achieved in treating the so-called motor symptoms, namely tremor, rigor and difficulties in walking (freezing, festinations) which affects the quality of life of these patients greatly. The aim of this study was to compare the quality of life in 95 patients suffering from Parkinson's disease pre- and post-operatively, more specifically, before and after the DBS stimulation of their STN. Namely, we assessed their ability to walk, eat and clothe without assistance as well as their overall subjective impression of their quality of life.

\section{Methods}

We analyzed 95 patients with DBS implantations which were performed in the Department of Neurosurgery at the University Hospital Dubrava for treating Parkinson's Disease from 2007 till 2015.
In this period over 200 patients were operated on, but these 95 were the ones which were analyzed by our nursing staff regarding their quality of life and independence in their everyday life. 36 female and 59 male patients were analyzed. Patients were asked to fill a questionnaire in which they were asked to assess their ability to clothe independently. They were provided with three possible answers: "I don't need assistance", "I sometimes need assistance" and "I always need assistance". The same answers were offered in order to assess their ability to walk and eat independently. They were also asked to rate their subjective independence in doing everyday tasks, being offered possible answers of "Independent", "Somewhat independent" and "Relying heavily on other people's help". They were questioned both before and after surgery (before and after the onset of the stimulation).

\section{Compliance with Ethical Standards}

Patients have given informed consent for participation in this paper.

The DBS procedure at our hospital is as follows. After a patient is accepted as a candidate for the DBS treatment he is admitted at the Department of neurosurgery for further surgical planning. DBS procedure contain several steps. The first step is a special MRI scan, using a special T2 sequence necessary for visualization of the subthalamic nuclei (STN) detailed neurosurgical planning. Immediately before the procedure Leksell's frame (Figure 1 ) is placed on the patient's head in order to put the head and brain in the $3 \mathrm{D}$ system. The frame is positioned by the doctor with a help of two nurses. Afterwards, computerized tomography (CT) is scanned and the patient is transferred to the operating room for further planning. In the meantime, a technician or a nurse prepares the device for neurosurgical planning (Stealth Station S7, Medtronic), electrodes for implantation, impedance measuring device Elekta and other instruments necessary for the surgery. MRI and CT image are being uploaded to Stealth Station S7 (Figure 2) and the neurosurgeon is using both scans for planning trajectory and target, STN (Figure 3). Leksell frame electrode entry point is determined using $X, Y$ and $Z$ plane. Then, surgical preparation of the operating field (washing and covering) is performed. The patient is under local anesthesia. After the incision, trepanation and opening of the dura the electrode is placed, first left then right or the other way around. 
Impedance is measured during surgery to avoid complications and to make sure that the electrode is in the correct position. After the implantation, control CT is made to establish the position of the electrodes.

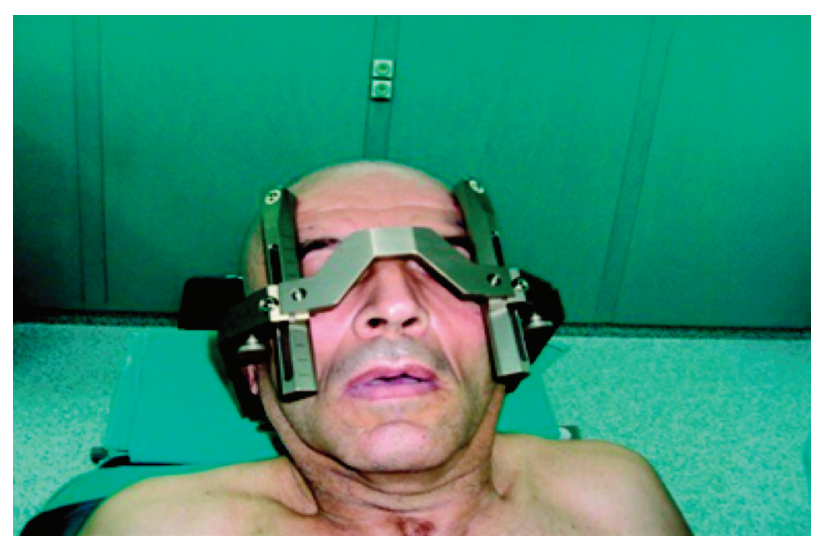

Figure 1. Setting the Leksell frame in local anesthesia

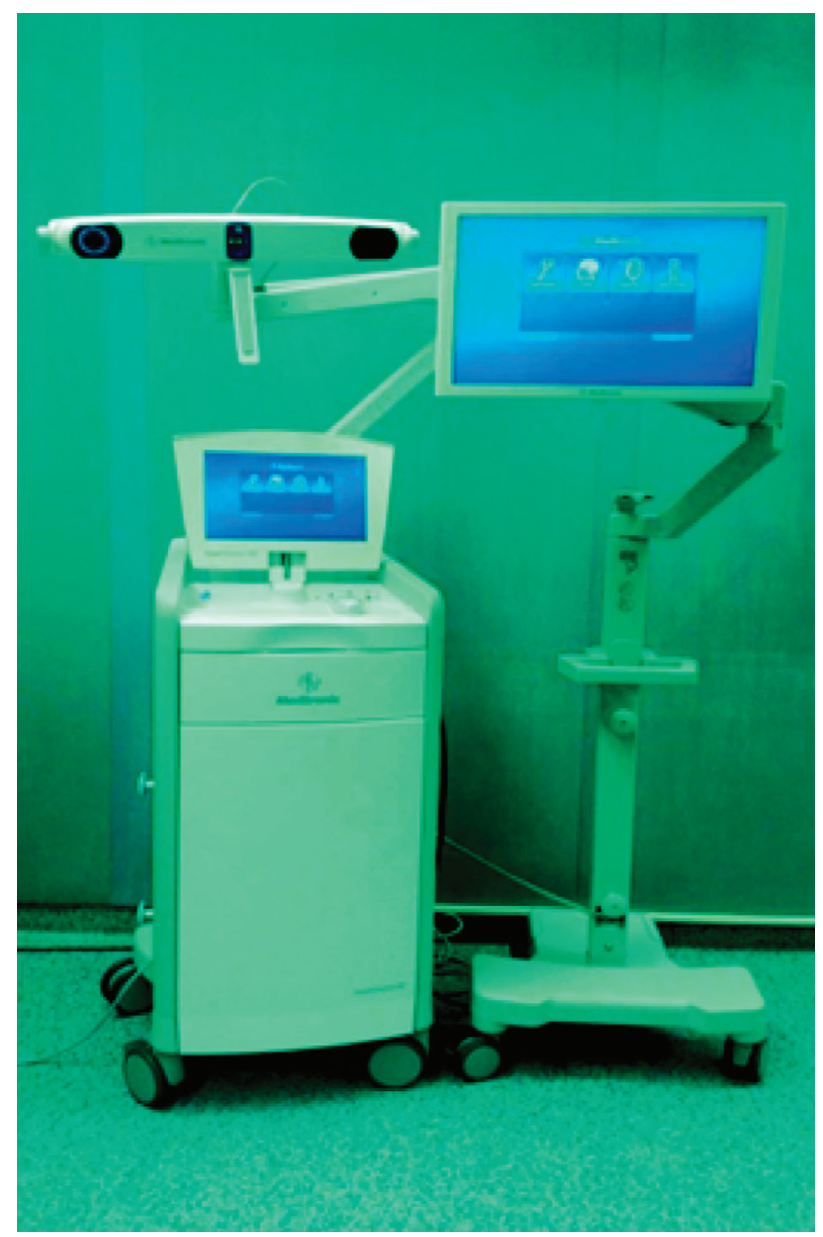

Figure 2. Device for DBS planning, StealthStation $\mathbf{S 7}$
If the position is correct and there are no signs of complications the second part of the surgery starts. The second part is performed in general endotracheal anesthesia. It consists of extension placement and connecting the electrode to the battery (Activa PC). The battery is placed subcutaneously in the left pectoral region. The stimulation starts on the $3^{\text {rd }}$ day after surgery and at that moment the patient usually experiences instant improvement.

\section{Results}

Ninety-five patients were examined before and after the beginning of stimulation.

Four graphs in Figure 4 show the results our patients reported on preoperatively. In assessing their walking ability, 20 patients noted that they always needed assistance, 57 of them noted how they sometimes need assistance, while 5 patients reported never having the need for assistance. For eating the results were as follows: 8 patients always needed assistance, 67 sometimes and 20 patients never needed assistance. In their assessment of their ability to clothe independently, 16 patients noted always needing assistance, 53 sometimes, while 26 patients

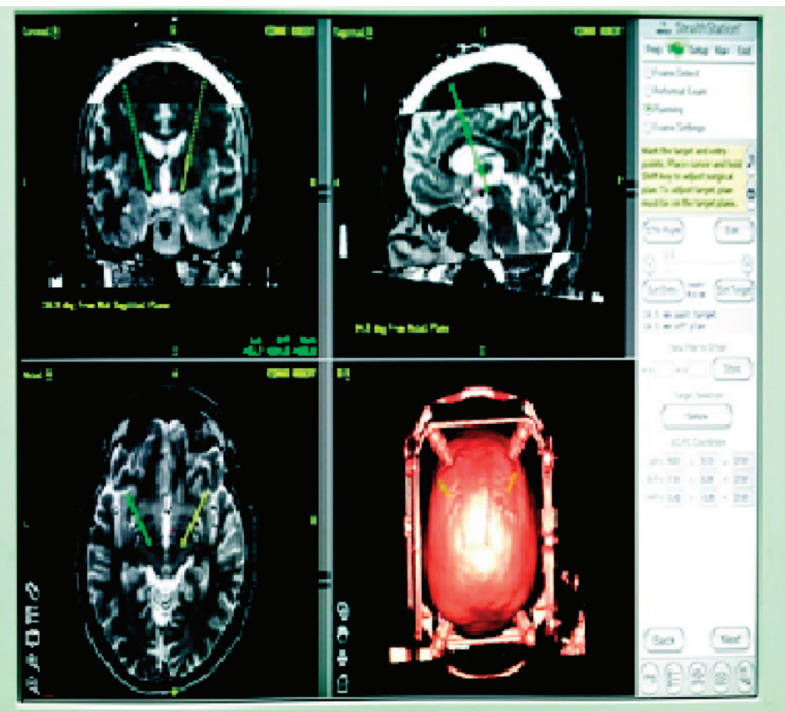

Figure 3. Target and trajectory planning on STN bilaterally as a part of DBS preparation 


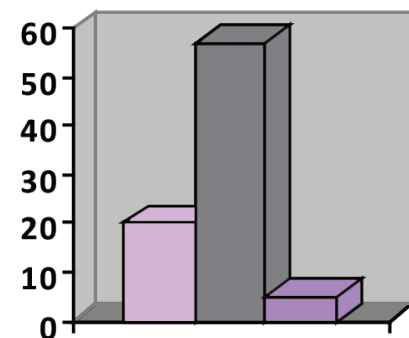

Assistance walking, preoperativelly

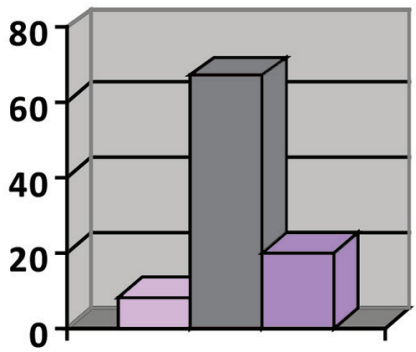

Assistance eating, preoperativelly

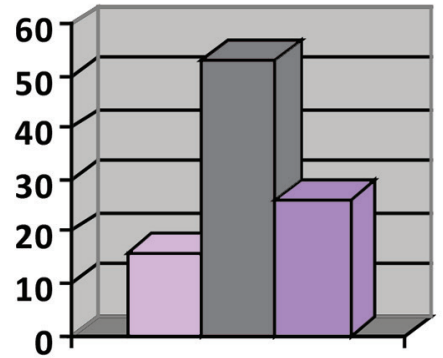

Assistance clothing, preoperatively

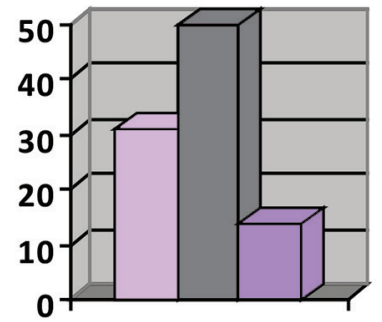

Subjective overall independence, preoperativelly

\begin{tabular}{|l|}
$\square$ Always \\
$\square$ Sometimes \\
$\square$ Never \\
\hline
\end{tabular}

\begin{tabular}{|l|}
$\square$ Always \\
$\square$ Sometimes \\
$\square$ Never \\
\hline
\end{tabular}

$\square$ Always

Sometimes

$\square$ Never $\square$ Independent

Somewhat independent

Heavily relying on others $\square$ Always

$\square$ Sometimes

$\square$ Never

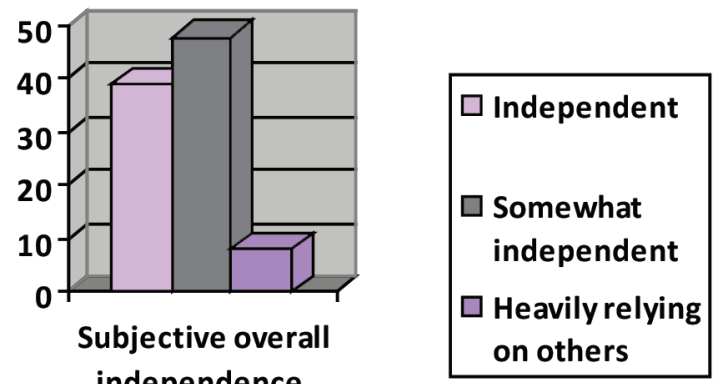

$\square$ Always

$\square$ Sometimes

$\square$ Never

$\square$ Always

$\square$ Sometimes

Never

Assistance eating,

postoperatively

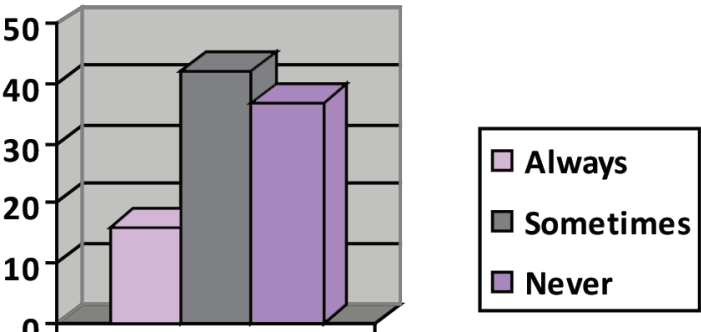

Assistance clothing, postoperatively on others 
noted how they never needed assistance. Finally, 31 patients reported their subjective feeling of their own independence in doing everyday tasks as "independent", 50 considered themselves as "somewhat independent", while 14 patients described themselves as completely dependent on another person.

Four graphs in Figure 5 show the results our patients reported on postoperatively. In assessing their walking ability, 11 patients noted that they always needed assistance, 66 of them noted how they sometimes needed assistance, while 18 patients reported never having the need for assistance after the beginning of the stimulation. For eating the results were as follows after the stimulation: 8 patients reported always needing assistance, 58 sometimes and 29 patients never needed assistance. In their assessment of their ability to clothe independently, 16 patients noted always needing assistance, 42 sometimes, while 37 patients noted how they never needed assistance. Finally, 39 patients reported their subjective feeling of their own independence in doing everyday tasks as "independent", 48 considered themselves as "somewhat independent", while 8 patients described themselves as completely dependent on another person.

There were no intraoperative complications i.e. hemorrhage or infection in the observed patient group. In extremely low weight patients, two cases of wound dehiscence were reported in the place of battery implantation (Activa PC) in the pectoral region.

\section{Discussion}

Today, DBS is an acceptable surgical method in treating Parkinson's Disease which, as mentioned before, has shown quite a high efficacy in treating especially the motor symptoms of the disease $(3,6)$. Complications are minimal, less than $1 \%$ (5). Indications for DBS play an important role and every patient has to go through very detailed neurological examination before the surgery. Complications of DBS procedure are not common and usually appear as: infection, intracranial bleeding, incorrect positioning of the electrodes, speech impediment and epileptic attacks $(4,5)$
As mentioned before, in their day-to-day lives patients usually have the most problems with their motor symptoms such as tremor and rigor. Fortunately, these are exactly the symptoms that DBS has the greatest success in relieving (3). Additionally, prolonged use of L-Dopa makes these patients dyskinetic and thus disables them further in their normal life. Lowering the dosage of the medication with DBS is thus an indirect way of improving the patient's condition.

Before the surgery, our patients reported having many difficulties in their normal day-to-day life due to their disease. The activities we decided to analyze were the ability to walk, clothe and eat independently and without the need for assistance, as well as the subjective feeling of their independence (see Fig 4). Of note is that our patients usually had quite an equal distribution of their difficulties, in a sense that none of the difficulties in performing these activities was predominant for everyone. Each patient was thus quite unique and viewed their difficulties differently. Also, of note is how our patients described themselves as independent and without the need for assistance even when they themselves said they sometimes needed assistance in everyday life. This goes to show just the resilience and mental attitude towards getting better, exhibited by most of our patients (here we must add that all our patients go through a rigorous psychological and psychiatric evaluation prior to surgery and any patient with signs of depression or mental problems isn't a candidate for DBS).

After the stimulation the results showed quite an improvement. As mentioned before, the motor symptoms are the ones which usually subside immediateIy, most notably the tremor and rigor. It is thus to be expected that, for example, eating or clothing without assistance is possible soon after surgery (see Fig 5). Festination and freezing during walking are also a major problem for patients which DBS shows great results in treating, thus allowing walking to be much easier and without assistance. Finally, of note is the fact that 11 more patients reported their subjective feeling of being without the need of assistance after the stimulation, showing how DBS helps with the subjective confidence and courage to fight the disease as well.

The main limitation of our study is that we primarily analyzed the subjective feeling of patients, who of course each have their own expectations and consideration regarding the disease, surgery and recov- 
ery. Also, we compared the data as a group of people without comparing the results further regarding sex and age. Nevertheless we feel our study clearly shows how DBS is an excellent treatment option which provides the patients with Parkinson's disease with a hope of alleviating their problems, helping them lead a normal life and allowing them to once again be fully integrated into society, all of which is in accordance to current knowledge and understanding of both Parkinson's disease and DBS.

\section{Conclusion}

In our experience, the usage of DBS procedure as a therapy method has been justified in the right conditions. It helps patients who suffer from progressive, disabling neurodegenerative diseases, and usually end in high impairment. DBS most commonly results in clinical and life quality improvement, which reflects to patients themselves, their families, surroundings and society in general. Using DBS, we have accomplished our main goals which are patient independence and partial or full work ability.

\section{References}

1. Winn RH. Youmans Neurological surgery. Sixth edition. Philadelphia: Elsevier Saunders; 2011.

2. Rengachary S, Ellenbogen R, Rengachary SS. Principles of neurosurgery. Second edition. Elsevier Mosby; 2004.

3. Moustafa AA, Chakravarthy S, Phillips JR, Gupta A, Keri $S$, Polner B, et al. Motor symptoms in Parkinson's disease: A unified framework. Neurosci Biobehav Rev. 2016;68:727-40.

4. Perlmutter JS, Mink JW. Deep brain stimulation. Annu Rev Neurosci. 2006;29:229-57.

5. Fukaya C, Yamamoto T. Systematic review of complications for proper informed consent (13) stereotactic and functional neurosurgery. No Shinkei Geka. 2014;42(8):751-68.

6. Lozano A, Gildenberg PL, Tasker RR. Textbook of Stereotactic and Functional Neurosurgery. Second edition. Springer-Verlag Berlin Heidelberg; 2009. 


\section{UTJECAJ DUBOKE MOZGOVNE STIMULACIJE NA KVALITETU ŽIVOTA BOLESNIKA S PARKINSONOVOM BOLEŠĆU}

\section{Sažetak}

Uvod. Duboka mozgovna stimulacija jest ciljana primjena električnih stimulacija na pojedine stanice središnjega živčanog sustava. Najčešća je primjena duboke mozgovne stimulacije kod neuroloških oboljenja kao što su Parkinsonova bolest, distonija, Touretteov sindrom i sl. Cilj je primjene duboke mozgovne stimulacije smanjenje medikamentozne terapije, poboljšanje motoričke funkcije, smanjenje boli i neurološkog deficita te poboljšanje kvalitete života.

Metode. Analizirali smo devedeset i pet dubokih mozgovnih implantacija učinjenih na Zavodu za neurokirurgiju Kliničke bolnice Dubrava u svrhu liječenja Parkinsonove bolesti u razdoblju od 2007. do 2015. godine. Svim je bolesnicima učinjena visokospecijalizirana operacija kojom se implantiraju elektrode u suptalamičku jezgru (STN) te se provedu ekstenzije i implantira baterija.

Rezultati. Četiri su parametra ispitana prije i poslije operacije: bolesnikova mogućnost samostalnog oblačenja, jedenja i hodanja te njihov osobni dojam kvalitete života i mogućnosti samostalnog života. Nakon stimulacije, ukupno gledajući, došlo je do poboljšanja u sve četiri navedene kategorije.

Zaključak. Duboka mozgovna stimulacija pokazala se posve opravdanom kod bolesnika s Parkinsonovom bolešću, pomažući u poboljšanju kvalitete života bolesnika.
Ključne riječi: duboka mozgovna stimulacija, Parkinsonova bolest, suptalamička jezgra 